\title{
Aquaculture State, Challenges and Technologies in the Middle East
}

\author{
Shaima Ibrahim Alameri1,a, Maitha Ahmed Almakhmari ${ }^{1, \mathrm{~b}}$, Sathiya Maran ${ }^{1, \mathrm{c}}$, Reem Yousef Almansoori, ${ }^{1, \mathrm{~d}}$, \\ Sabra Ahmed Alqubaisi ${ }^{1, \mathrm{e}}$, Aisha Abushelaibi, ${ }^{1, \mathrm{f}}$, Kok-Song Lai ${ }^{1, \mathrm{~g}}$, Swee-Hua Erin Lim ${ }^{1, \mathrm{~h}, *}$
}

Health Sciences Division, Abu Dhabi Women's College, Higher Colleges of Technology, 41012 UAE *Corresponding author

\begin{tabular}{l|l} 
A R T I C L E I N F O & A B S T R A C T \\
\hline $\begin{array}{l}\text { Review Article } \\
\text { Received : } 11 / 05 / 2021\end{array}$ & $\begin{array}{l}\text { The aquaculture industry in the Middle East (ME) is still relatively new compared to other parts of } \\
\text { the world, making this region highly dependent on other countries for the production of food and } \\
\text { feed needs. Aquaculture activities in the world at current is mainly focused in China; this may be } \\
\text { propelled by its own internal demand for seafood as determined by the United Nations Food and } \\
\text { Agriculture Organization (FAO). Challenges faced in the ME has not been elucidated so far and the } \\
\text { issues arising might be unique only to this region due to aquaculture being in the initial stages } \\
\text { coupled with water access and limitations, climate and geography, in addition to pollution. This } \\
\text { review paper will present and discuss global needs for seafood focusing later on the needs in the } \\
\text { ME, followed by a discourse into the importance, types and challenges of aquaculture in the ME. } \\
\text { Baseline knowledge and infrastructure to enhance knowledge is a pressing need at this stage of } \\
\text { infancy. It is hope this sector will continue to develop, and with the support of stakeholders, } \\
\text { aquaculture in the ME will achieve a state of independence. }\end{array}$ \\
$\begin{array}{l}\text { Keywords: } \\
\text { Aquaculture } \\
\text { Middle east }\end{array}$ &
\end{tabular}

Challenges

Technologies

Fish diseases

\begin{abstract}
The aquaculture industry in the Middle East (ME) is still relatively new compared to other parts of the world, making this region highly dependent on other countries for the production of food and propelled by its own internal demand for seafood as determined by the United Nations Food and Agriculture Organization (FAO). Challenges faced in the ME has not been elucidated so far and the issues arising might be unique only to this region due to aquaculture being in the initial stages coupled with water access and limitations, climate and geography, in addition to pollution. This aquaculture in the ME will achieve a state of independence.
\end{abstract} shaimaalameri97@hotmail.com
'@ sathiya.maran@monash.edu
'@lkoksong@hct.ac.ae
(iD) http://orcid.org/0000-0001-5589-5946 iD https://orcid.org/0000-0001-5617-901X (iD) https://orcid.org/0000-0003-0150-8976 (iD) http://orcid.org/0000-0002-1887-2232

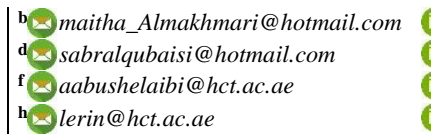
http://orcid.org/0000-0002-0044-6024 https://orcid.org/0000-0002-0693-4192 http://orcid.org/0000-0002-2372-893X http://orcid.org/0000-0001-5177-0257

\section{Introduction}

Aquaculture is the process of rearing, breeding and harvesting of aquatic species in a controlled aquatic environment and is defined by The United Nations Food and Agriculture Organization (FAO) as "The farming of aquatic organisms including fish, molluscs, crustaceans and aquatic plants". Farming indicates some sort of intervention in the rearing process to increase production, such as regular stocking, feeding and protection from predators. Farming also signifies individual or corporate ownership of the stock being cultivated. Therefore, although aquaculture is a mechanism to produce food and the benefits far outweigh the adverse effects, in addition to positively improving economy, the possible consequences of the process affecting the environment and increasing concerns regarding the health of consumers remain (Ruiz-Chico et al., 2020).

Aquaculture has been reported as a component of a complex global food system that is progressively changing and growing (Fiorella et al., 2021). The increase in demand for seafood yearly is largely due to an increase in with the worldwide population. A recent report cited that between 2000 and 2012, aquaculture has doubled its global fish production rate to meet the world's current demand. Nonetheless, the present production of aquaculture needs to be increased to more than double to adequately meet the rapidly growing demand (Waite et al., 2014). Global demand for seafood is predicted to increase over the years and FAO has reported that an excess value of 40 million extra tons of seafood, which is a rise of almost $30 \%$, will be needed to meet the growing demand by 2030 . The United States is considered to be one of the largest importers of seafood by value. In 2018, the total import value of eatable and uneatable seafood products was USD 40.3 billion, however this has increased to USD 1.9 billion or 5\% USD compared with 2017 (Mordor Intelligence, 2020). 
To date, most aquaculture activity takes place in Asia, particularly in China. The dramatic expansion of China's aquaculture for the past decade has contributed for most of the fish consumed by the people around the world. This has created a good source of income, leading towards food security and economic growth (FAO, 2014).

The Middle East (ME) is surrounded by seven seas; The Persian Gulf, mediterranean, the Gulf of Aden, the red Sea, the Black Sea, the Caspian Sea and the Arabian sea; this makes the region a good source for fresh seafood (Towers, 2014). However, at current, there is limited information pertaining the importance, significance and challenges of aquaculture in the ME.

This review aims to provide an overview of aquaculture scene in the ME, focusing on its challenges, technologies and future prospect. This will not only help to enhance knowledge in aquaculture development, types, and fish production in Asia and the Middle East but also provide insight into understanding the challenges among fish farmers for future innovations and expectations in the aquaculture sector in this region.

\section{Importance of Aquaculture}

Aquaculture or "aquatic animal and plant farming" is an integral part of human culture, health and economies; it has significantly filled the gap of seafood demand (Tidwell \& Allan, 2001, Love et al., 2017). Recent reports described that seafood supports about $10-12 \%$ of the world population and is considered a part of a healthy nutrition, providing almost 3 billion people with $20 \%$ of dietary protein needs and micronutrients (Love et al., 2017).

In terms of health and nutritional benefits of fish and aquatic foods, seafood offers a healthier food source than terrestrial meat products because seafood has a higher protein content, lower caloric density, high content of omega-3 polyunsaturated fatty acids, higher mineral and vitamin; vitamin $D$, vitamin $A$, folic acid, vitamin $B_{12}$, vitamin $\mathrm{E}$, coenzyme $\mathrm{Q}_{10}$, choline, calcium, minerals, copper, magnesium, zinc, iron, iodine and selenium (Tacon, Lemos and Metian 2020). Consumption of seafood is widely promoted as an excellent source of easily digestible protein and essential fatty acids that are essential for metabolic functions (Norman et al., 2019).

Scientific reports have described the health benefits of consuming fishery and fish products especially towards reduced risk of death from heart disease such as coronary heart disease and stroke (Trivedi et al., 2021, Tani et al., 2021, Forouhi et al., 2018, WHO \& FAO, 2011), reduction in the risks of diabetes (Chen et al., 2021), improved visual and cognitive development as well as increased duration of gestation (Hellberg et al., 2012), improved neurodevelopment in infants and children when fish is consumed before and during pregnancy (Hamazaki et al., 2020), and finally, reduction the risks of thyroid cancer (Cléro et al., 2012).

The prominent role of aquaculture towards food security is synonymous. The term "food security" is defined as the need to have access at all times to adequate provision and absorption of nutrients in food to garner a healthy and active life (FAO, 1996). In 2016, an increase of more than $20 \mathrm{~kg}$ per year of global per capita fish consumption was observed, this made up $6.7 \%$ of all protein consumed by humans (FAO, 2018). FAO reported that China has the highest overall consumption for fish followed by India and the rest of Asia, and the consumption is predicted to increase globally over the next few years (FAO, 2018).

\section{Importance of Aquaculture in the $M E$}

In the ME, aquaculture is one of the fastest growing sectors, largely due to the highest product traceability standards and safety, rigorous biosecurity, and state-of-theart technology. The aquaculture production of $\mathrm{ME}$ has increased speedily from 837,247 tonnes in 2005 to $1,768,917$ tonnes in 2014 , with an approximate of $111 \%$ increment, and has been predicted to increase to 2.4 million tonnes in near future (Tolon, 2017).

The significant demand for seafood from aquaculture over the last few decades is mainly due to the increase of seafood consumption per capita in the region. For instance, the United Arab Emirates (UAE) recorded a total of 51.1 $\mathrm{kg}$ per capital consumption of seafood, which is one of the highest in the world and four times the world average. This is followed by Oman $(36.7 \mathrm{~kg} /$ per year), Bahrain (16.9 $\mathrm{kg} /$ per year) and Qatar (16.5 kg/per year) (Chibber, 2013). The upsurge of seafood consumption in these gulf countries is due to the increase in population growth, tourism numbers, and the rise in incomes per capita (Napier, 2014). Despite its huge demand and consumption, total seafood production in the ME is only about $2.17 \%$ of the total international production (Middle East Fish and Seafood Market (2020-2026), 2020).

Highest fish consumption in ME is reported by United Arab Emirates (UAE), Oman, Qatar, Bahrain and part of South Yemen (Towers, 2014). As maintained by The Environment Agency Abu Dhabi (EAD), aquaculture amounted to about 810 tonnes the production in Abu Dhabi alone of aquatic specieses with a value of approximately USD 5.06 million representing a $20 \%$ growing in production in 2018. The Food and Agriculture Organisation (FAO) also reported that over the past three years, tuna fish production was recorded to be 19,700 tonnes, whereas in 2016 the pelagic fish's production was 10,480 tonnes that in 2018 increased to 10,550 tons. A recent report by Chalil and colleagues described that about $44 \%$ of the total seafood production in the ME is sourced mostly from Egypt, Iran and Turkey (Chalil, 2019).

\section{Types of Aquacultures in the ME}

Aquaculture can be sub-grouped to mariculture, algaculture and multi-trophic aquaculture (Bert, 2007). Mariculture is the aquaculture outlet that grows aquatic animals in the exposed marine or an enclosed part of the ocean or tanks or ponds filled with seawater (Nash, 2011). Mariculture is denoted as a subgroup of the bigger aquaculture sector, involving the cultivation of both freshwater and marine organisms (Phillips, 2009). Algaculture is the form of aquaculture that produces algae in a controlled temperature, source of light and dietary properties (Lucas et al., 2019). The integrated multitrophic aquaculture (IMTA) is an evolved aquaculture system which combines different species with distinct nutritional needs into one framework (Grosso et al., 2021). An example of this method is growing seaweed which 
utilises ammonia and phosphorus excreted by fish and shrimp while oyster fish feed on the solids produced by fish and shrimps.

In ME especially in the UAE, fishing is primarily conducted from the open fibreglass dories and traditional wooden dhows. Dome shaped wire traps are the most commonly used fishing gear although a variety of other methods exist including; gillnets, fixed inter-tidal fence nets, trolling lines and hand lines (Shallard et al., 2010).

In UAE, the types of aquaculture are divided into landbased and sea-based aquaculture. Land-based aquaculture includes the ponds, fence, closed system aquaculture RAS (Recirculation aquaculture system) and integrated aquaculture (McLean, 2003) whereas, sea-based aquaculture uses cages, coastal fences and suspended aquaculture systems. Another common aquaculture type is the sea-based aquaculture, whereby floating cages or nets composed of a wooden frame, netting or fabric is used. Besides the mentioned, UAE also employs multiple systems, ranging from comparatively easy systems such as basins, lakes, integrated aquaponics and aquaculture to compound systems based on technology, including the RAS.

\section{Challenges and limitations of Aquaculture}

Aquaculture is still a developing economic sector in ME. The governments have been promoting this sector in Oman, UAE and KSA by supplying fingerlings of regional species, developing a framework for aquaculture, reducing investment constraints and relaxing institutional policies, in addition to mapping out suitable sites (Lavieren et al., 2011). The main challenges and limitation faced in the ME is limited availability to freshwater and suitable soil, insufficient tidal amplitude of land-based culture and restrictions in the availability of suitable marine sites (JanDec, 2016). Another main issue in the region is the highwater evaporation and highly fluctuating air temperature rates which can make water temperature and salinities rise above acceptable level for many farmed species.

\section{Fishmeal}

Fishmeal is the main protein source for farmed species in their diet. Growing aquaculture industry increased the need for fishmeal which proportionately leads to increased demand and price (Olsen \& Hasan, 2012). In the early nineties the average cost of fishmeal was approximately 400-500 USD/tonne, and a steady increase was observed with the price reaching to 1200 USD/tonne from 2002 till 2017. One of the factors that contributed to this issue is because feed fish may have been directly used for population consumption in addition to decrease in feed fish catch due to unregulated fishing and stricter quota settings (Tacón et al., 2011). Furthermore, fishmeal is being widely used as an important component in feed for meat producing animals and poultry, due to its high nutritional quality. Studies have been carried out in addressing this issue and one of the solutions was to use plant proteins with improved nutritional benefits replacing fishmeal in aquaculture diets (Olsen \& Hasan, 2012). Apart from plant proteins, terrestrial animal by-product meals such as bone and meat meal, poultry by-product and blood meals are also considered feed ingredients of good nutritional quality
(Tacon et al., 2006). Furthermore, bacterial protein meal has also being produced as a source of fishmeal and it has shown to benefit salmons as feeds in the Atlantic

(Bendiksen et al., 2011, Aas et al., 2006, Berge et al., 2005).

\section{Pollution}

Pollution is another main challenge faced in aquaculture. With the increasing demand of aquaculture production, an increased pollution and impact on the environment is also observed. Pollution in aquaculture is attributed to nutritional, genetic, chemical as well as disease affliction and invasive species. Nutrient pollutions are uneaten feed pellets, feed fines and faecal material which accumulates below culture cages. And finally, diseases infecting fishes would affect the local marine ecosystem. Antibiotics, antiparasitic, fungicides, biologics, hormones, chemical solutions and compounds used for therapeutic control of diseases uncontrolled used leads to aquatic biodiversity toxicity, residue accumulation, microbial community selection for emergence of multiantibacterial resistant strains and antibiotic resistance (Lulijwa et al., 2020).

\section{Aquatic Environment Additives}

Water additives are added to fish farms for several reasons including enhancing the growth of aqua organisms, providing nutrients as well as protection, prevention from diseases and finally, to provide a more natural environment to the animals (Flegel, 1998). Uncontrolled use of water additives affects the production capacity and water quality (Dauda et al., 2019). This may cause issues such as overgrowth of algae and accumulation of inorganic elements that are toxic to aquatic animals and the environment. For instance, oxidation reaction between ammonium (derived from fish waste) and bacteria (derived from probiotics) will lead to accumulation of toxic substances such as nitrite $\left(\mathrm{NO}^{2-}\right)$ and nitrate $\left(\mathrm{NO}^{3-}\right)$ (Avnimelech, 1999). In addition, in 2014, an environmental pollution happened in Vietnam due to the overusing of inorganic chemicals in aquaculture (Bui et al., 2016).

\section{Climate Change}

Climate change is another challenge faced in the aquaculture sector, it causes significant mortalities among aquatic creatures such as fish, plants, corals, and mammals (Barange et al., 2018). High temperatures cause negative effects on the physiology of fish due to lowered ability to transport oxygen to tissues. In addition, growth of harmful algal due to infrastructure arising from extreme events such as floods could occur and an increased susceptibility to bacterial infections due to climate change is also a challenge (Cochrane et al., 2017).

\section{Bacterial Infection and Antimicrobial Resistance}

Bacterial infections in aquaculture causes billions of dollars lost per year due to pathogens; these include viral and parasitic infections. A common infection is the Aeromonas hydrophila which causes motile aeromonad septicaemia (MAS), a disease in fish that can spread with environmental contamination or direct contact with sick fish (Zmysłowska et al., 2009); the MAS disease leads to high rate in mortality and high economic losses. 
Chryseobacteriosis, a skin syndrome affecting salmons, caused by Chryseobacterium species, is a fish spoilage agent and it is classified mainly as a freshwater disease (Pridgeon \& Klesius, 2012). Infectious diseases are the major cause of the increased mortality rate in fish stock (Sudheesh et al., 2012). Disease outbreaks are also responsible for the loss of supplements during the farming process which increases economic losses (Bui et al., 2016). Major bacteria that can cause contamination to aquatic products are Vibrio species, Nocardia, Aeromonas, Streptococcus, Flavobacterium, Yersinia, Edwardsiella, Lactococcus, Renibacterium, and Mycobacterium (Granada et al., 2015, Sudheesh et al., 2012).

Antimicrobial resistance is one of the global public health issues for both humans or animals. The overuse of antimicrobial drugs in aquaculture will lead to the development of resistant microorganisms. For example, Vibrio isolated from a shrimp pond indicated its resistance to oxytetracycline (4.3\% of the whole number of isolation) and furazolidone in $(1.6 \%$ of the whole number of isolation) (Tendencia \& de la Peña, 2001). In addition, Salmonella spp. showed resistance to several antibiotics such as oxalinic acid and oxytetracycline (Alcaide et al., 2005). Furthermore, in Iran, E. coli showed 100\% resistance to gentamycin, ciprofloxacin, chloramphenicol, ampicillin and tetracycline (Tajbakhsh et al., 2015).

\section{Genetic Pollution}

Aquaculture species that escape from farms have the potential to create major environmental problems; this is known as "Genetic pollution" (Grewe et al., 2007). These include establishment of potentially destructive feral populations and intro-aggression of foreign genes into natural populations from both genetically modified fish and hatcheryreared fish and invertebrates. The interbreeding of feral cultured fish and wild fish can have drastic genetic effects on local wild species. It may create new species with lower immunity against disease and parasites in the wilderness or create dominant fishes that will overrun the existing ones. This could pose a threatening condition to countries like ME which is surrounded by seven seas that could forsee a quick spreading of genetic pollution. These scenarios can be avoided by employing molecular engineering solutions that enables fish to be fertile under hatchery conditions and functionally sterile outside of captivity (Grewe et al., 2007).

\section{Aquaculture Technologies, Trainings and Education}

Technologies in aquaculture have been reported to play an important function in delivering enhanced food security with a holistic approach that encompasses the complete value chain (Little \& Bunting, 2016).

Surface-enhanced Raman scattering (SERS) is widely used for pathogen detection and has also been proven to be sensitive for trace chemical detection; a broad range of target including bio- and nonbiomaterials (DNA, metabolites, pesticides, and proteins) can be detected ( $\mathrm{Lu}$ $\&$ Serajuddin, 2020). Another important aspect of aquaculture is disease prevention. Probiotics, for instance, have been used to improve immunity and enhance shrimp health. RNA interference (RNAi) is being tested by multiple emerging and established companies. Another promising innovation in tackling disease prevention is the oral delivery of vaccines which is a boon in terms of efficiency and ease of use, and is suitable for all ages and sizes of fish. It reduces handling and damage to fish, can be used repetitively as fish mature and could prove to be less costly while yielding lower mortality rates.

The Marine environment Research Centre (MREC) with Ministry of Environment and Water, UAE have been focussing in aquaculture developments in ME. One of the main initiatives is re-stocking the waters with local species by producing fingerlings, such as white spotted spinefoot, orange spotted grouper, large scale mullet and sobaity sea bream (Jan-Dec, 2016). Besides this, in the UAE other developments such as $360,000 \mathrm{~m}^{2}$ fish reserve was allocated in the coast of Fujairah to encourage fishermen to adopt sustainable fishing methods (Region's Largest Fish Reserve Launched, 2013), a 56,000 $\mathrm{m}^{2}$ Siberian caviar farm in Abu Dhabi which produces 700 tons of sturgeon meat and 35 tons of caviar per year (Towers, 2013), and a land based $500,000 \mathrm{~m}^{2}$ salmon, grouper and sea bream RSA farm in Abu Dhabi (Churchill, 2014).

In terms of aquaculture development in Saudi Arabia 66.7 million Saudi riyals have been allocated to benefit small scale agriculture producers and fishermen in providing technical assistance and expertise in 17 initiatives and covers transfer of technology, sustainable management of natural resources, sustainable crop production, management of fisheries resources and strengthening of rural institutions (Towers, 2012).

In terms of aquaculture education and trainings in the $\mathrm{ME}$, a shortage of experienced management and skilled aquaculture technicians have been reported. To date only the King Abdul Aziz University in Jeddah and King Faisal University in Al-Ahsa offers undergraduate aquaculture courses. Training and guidance have also been given by the Ministry of Agriculture and Water, and King Abdul Aziz City for Science and Technology in encouraging aquaculture development (Mubarak \& Eide, 2009).

\section{Conclusion}

ME countries rely largely on other countries to meet local feed and food requirements. The rising demands due to increasing population, combined with the need to reduce dependency on imports, have been adding to the potential for aquaculture these developing markets. However, there are main challenges such as pollutions, inadequate offshore sites and limited expertise that need to be addressed. Moreover, technology can be used to overcome the challenges by reducing disease outbreaks or to enhance fish immunity. Aquaculture's future directions require refinement of present methods; technological developments are needed to increase in recirculating systems and aquaponic systems. These systems can then promote aquaculture to be practiced nearly everywhere, including marine species cultivation in places far from the coast.

\section{Acknowledgement}

The authors are grateful to the Ministry of Climate Change \& Environment UAE and to the Higher Colleges of Technology 


\section{References}

Aas TS, Grisdale-Helland B, Terjesen BF, Helland SJ. 2006. Improved growth and nutrient utilisation in Atlantic salmon (Salmo salar) fed diets containing a bacterial protein meal. Aquaculture, 259(1-4): 365-376 [Accessed 1.11.2021]

Alcaide E, BlascoMD, Esteve C. 2005. Occurrence of drugresistant bacteria in two European eel farms. Applied and Environmental Microbiology, 71(6): 3348-3350. https://doi.org/10.1128/AEM.71.6.3348-3350.2005 [Accessed 1.11.2021]

Avnimelech Y. 1999. Carbon/Nitrogen Ratio as a Control Element in Aquaculture Systems. Aquaculture, 176, 227-235

Barange M, Bahri T, Beveridge MCM, Cochrane KL, Smith SF, Poulain F. 2018. Impacts of climate change on fisheries and aquaculture: Synthesis of current knowledge, adaptation and mitigation options. Food and Agriculture Organization [Accessed 1.11.2021]

Bendiksen EÅ, Johnsen CA, Olsen HJ, Jobling M. 2011. Sustainable Aquafeeds: Progress Towards Reduced Reliance Upon Marine Ingredients in Diets for Farmed Atlantic Salmon (Salmo salar L.). Aquaculture, 314: 132-139.

Berge G, Baeverfjord G, Skrede A, Storebakken T. 2005. Bacterial Protein Grown on Natural Gas as Protein Source in Diets for Atlantic Salmon, Salmo Salar, in Saltwater. Aquaculture, 244: 233-240.

Bert T. 2007. Ecological and genetic implications of aquaculture activities. Springer Science \& Business Media. ISBN 978-14020-6148-6.

Bui DH, Bui DPH, Pham QT. 2016. The factors affecting chemical use in aquaculture in the Central Coast Region of Vietnam. Cogent Food and Agriculture, 2(1): 1207398. https://doi.org/10.1080/23311932.2016.1207398

Chalil G. 2019. The new investment wave into aquaculture in middle east countries: Opportunities and challenges. Food and Agriculture Organization of the United Nations. http://www.fao.org/in-action/globefish/fishery-information/ resource-detail/en/c/338614/ [Accessed 10 February 2021]

Chen GC, Arthur R, Chen LH, Mei Z, Zheng Y, Li Y, Wang T, Rohan TE, Qi Q. 2021. Association of Oily and Nonoily Fish Consumption and Fish Oil Supplements with Incident Type 2 Diabetes: A Large Population-Based Prospective Study. Diabetes Care, 44(3): 672-680. https://doi.org/10.2337/dc202328

Chibber A. 2013. Middle East Hungry for More Seafood. FoodNavigator. https://www.foodnavigator.com/Article/2013/12/04/MiddleEast-hungry-for-more-seafood [Accessed 25 February 2021]

Churchill N. 2014. UAE Salmon Farms: A Big Catch. Gulf Business. https://gulfbusiness.com/uae-salmon-farms-bigcatch/ [Accessed 12 February 2021]

Cléro É, Doyon F, Chungue V, Rachédi F, Boissin JL, Sebbag J, Shan L, Bost-Bezeaud F, Petitdidier P, Dewailly E, Rubino C, de Vathaire F. 2012. Dietary Iodine and Thyroid Cancer Risk in French Polynesia: A Case-Control Study. Thyroid: Official Journal of the American Thyroid Association, 22(4): 422-429. https://doi.org/10.1089/thy.2011.0173

Cochrane K, Young CD, Soto D, Bahri T. 2017. Climate change implications for fisheries and aquaculture. In B. F. Phillips and M. Pérez-Ramírez (Eds.), Climate Change Impacts on Fisheries and Aquaculture (pp. 45-62). John Wiley and Sons, Ltd. https://doi.org/10.1002/9781119154051.ch3

Dauda AB, Ajadi A, Tola-Fabunmi AS, Akinwole AO. 2019. Waste Production in Aquaculture: Sources, Components and Managements in Different Culture Systems. Aquaculture and Fisheries, 4(3): 81-88. https://doi.org/10.1016/j.aaf.2018.10. 002

FAO, 1996. Rome Declaration on World Food Security and World Food Summit Plan of Action: World Food Summit. Food and Agriculture Organization of the United Nations. https://www.fao.org/3/w3613e/w3613e00.htm
FAO, 2011. Markets in the Middle East: Market, Trade and Consumption. Food and Agriculture Organization of the United Nations. http://www.fao.org/in-action/globefish/ fishery-information/resource-detail/en/c/338542/

FAO, 2014. The state of world fisheries and aquaculture 2014. Food and Agriculture Organization of the United Nations. http://www.fao.org/policy-support/resources/resourcesdetails/en/c/416712/

FAO, 2018. The State of World Fisheries and Aquaculture 2018: Meeting the Sustainable Development Goals. Food and Agriculture Organization of the United Nations.

Fiorella KJ, Okronipa H, Baker K, Heilpern S. 2021. Contemporary aquaculture: Implications for human nutrition. Current Opinion in Biotechnology, 70: 83-90. https://doi.org/10.1016/j.copbio.2020.11.014

Flegel TW. 1998. Advances in Shrimp Biotechnology. National Center for Genetic Engineering and Biotechnology [Accessed on 6.10.21]

Forouhi NG, Misra A, Mohan V, Taylor R, Yancy W. 2018. Dietary and Nutritional Approaches for Prevention and Management of Type 2 Diabetes. Thebmj, 361: k2234. https://doi.org/10.1136/bmj.k2234

Granada L, SousacN, LopescS, LemoscM. 2015. Is integrated multitrophic aquaculture the solution to the sectors' major challenges? - A review. Reviews in Aquaculture, 8: 283-300. https://doi.org/10.1111/raq.12093

Grewe PM, Patil JG, McGoldrick DJ, Rothlisberg PC, Whyard S, Hinds LA, Hardy CM, Vignarajan S, Thresher RE. 2007. Preventing Genetic Pollution and the Establishment of Feral Populations: A Molecular Solution. In T. M. Bert (Ed.), Ecological and Genetic Implications of Aquaculture Activities (pp. 103-114). Springer Netherlands. https://doi. org/10.1007/978-1-4020-6148-6_6

Grosso L, Rakaj A, Fianchini A, Morroni L, Cataudella S, Scardi M. 2021. Integrated Multi-Trophic Aquaculture (IMTA) System Combining the Sea Urchin Paracentrotus Lividus, as Primary Species, and The Sea Cucumber Holothuria Tubulosa as Extractive Species. Aquaculture, 534: 736268.

Hamazaki K, Matsumura K, Tsuchida A, Kasamatsu H, Tanaka T, Ito M, Inadera H. 2020. Maternal Dietary Intake of Fish and PUFAs and Child Neurodevelopment at 6 months and 1 Year of Age: A Nationwide Birth Cohort-The Japan Environment and Children's Study (JECS). The American Journal of Clinical Nutrition, 112. https://doi.org/10. 1093/ajcn/nqaa190

Hellberg R, Mireles DeWitt C, Morrissey M. 2012. Risk-Benefit Analysis of Seafood Consumption: A Review. Comprehensive Reviews in Food Science and Food Safety, 11. https://doi.org/10.1111/j.1541-4337.2012.00200.x

Jobling M. 2011. CE. Nash: The history of aquaculture. Aquaculture International, 19(6): 1231. https://doi.org/10.1007/s10499-011-9465-5

Lavieren H, van Burt J, Feary DA, Cavalcante G, Marquis E, Benedetti L, Trick C, Kjerfve B, Sale PF. 2011. Managing The Growing Impacts of Development on Fragile Coastal and Marine Ecosystems: Lessons from The Gulf: Policy Report. [Accessed on 7.07.2021]

Little D, Bunting S. 2016. Aquaculture Technologies for Food Security. In Emerging Technologies for Promoting Food Security: Overcoming the World Food Crisis (pp. 93-113). https://doi.org/10.1016/B978-1-78242-335-5.00005-6

Love D, Pinto da Silva P, Olson J, Fry J, Clay PM. 2017. Fisheries, Food, and Health in the USA: The Importance of Aligning Fisheries and Health Policies. Agriculture and Food Security, 6. https://doi.org/10.1186/s40066-017-0093-9

Lu Q, Serajuddin M. 2020. Emerging Technologies, Environment and Research for Sustainable Aquaculture. IntechOpen. https://doi.org/10.5772/intechopen.82887 
Lucas JS, Southgate PC, Tucker CS. 2019. Aquaculture: Farming Aquatic Animals and plants. Wiley-Blackwell, 30(2): 664.

Lulijwa R, Rupia EJ, Alfaro AC. 2020. Antibiotic Use in Aquaculture, Policies and Regulation, Health and Environmental Risks: A Review of The Top 15 Major Producers. Reviews in Aquaculture, 12(2): 640-663. https://doi.org/10.1111/raq.12344

McLean E. 2003. Responsible Marine Aquaculture. R.R. Stickney and J.P. McVey (eds). Aquaculture International, 11(3): 313-316. https://doi.org/10.1023/A:1024844120406

Mordor Intelligence. 2020. Global Seafood Market | 2021-26 | Industry Share, Size, Growth-Mordor Intelligence (No. 5119579; p. 80). https://www.mordorintelligence.com/ industry-reports/global-seafood-market

Mubarak MM, Eide BR. 2009. INBDP Aquaculture in The Middle East 2009. Innovation Norway, 42. [Accessed on 7.07.2021]

Napier M. 2014. Capitalising On the Middle East's Rising Food Demand. Gulf Business. https://gulfbusiness.com/ capitalising-middle-easts-rising-food-demand/

Norman RA, Crumlish M, Stetkiewicz S. 2019. The Importance of Fisheries and Aquaculture Production for Nutrition and Food Security. Revue Scientifique Et Technique (International Office of Epizootics), 38(2): 395-407. https://doi.org/10.20506/rst.38.2.2994

Olsen RL, Hasan MR. 2012. A Limited Supply of Fishmeal: Impact on Future Increases in Global Aquaculture Productio. Trends in Food Science and Technology, 27(2): 120-128. https://doi.org/10.1016/j.tifs.2012.06.003

Phillips M. 2009. Mariculture Overview. In J. H. Steele (Ed.), Encyclopedia of Ocean Sciences (Second Edition) (pp. 537544). Academic Press. https://doi.org/10.1016/B978012374473-9.00752-9

Pridgeon JW, Klesius PH. 2012. Major Bacterial Diseases in Aquaculture and their Vaccine Development. U.S.Department of Agriculture, 7(048): 1-16 [Accessed on 29.06.21]

Ruiz-Chico J, Biedma-Ferrer JM, Peña-Sánchez AR, JiménezGarcía M. 2020. Social Acceptance of Aquaculture in Spain: An Instrument to Achieve Sustainability for Society. International Journal of Environmental Research and Public Health, 17(18). https://doi.org/10.3390/ijerph17186628

Shallard B, Al-Oufi H, Bose S, Grandcourt E. 2010. Resource assessment surveys as the basis for effective fisheries management. International Institute of Fisheries Economics and Trade, Montpellier, France [Accessed on 14.07.21]

Sudheesh PS, Al-Ghabshi A, Al-Mazrooei N, Al-Habsi S. 2012. Comparative Pathogenomics of Bacteria Causing Infectious Diseases in Fish. International Journal of Evolutionary Biology, 2012. https://doi.org/10.1155/2012/457264

Tacon AGJ, Hasan MR, Subasinghe RP. 2006. Use of Fishery Resources as Feed Inputs to Aquacultuer Development: Trends and Policy Implications (No. 1018; p. 99). FAO Fisheries Circular https://www.fao.org/3/a0604e/a0604e00. htm

Tacon A, Hasan M, Metian M. 2011. Demand and Supply of Feed Ingredients for Farmed Fish and Crustaceans: Trends and Prospects (No. 564; p. 87). FAO Fisheries and Aquaculture Technical Paper https://www.fao.org/apfic/publications/ detail/en/c/419609/
Tajbakhsh E, Khamesipour F, Ranjbar R, Ugwu IC. 2015. Prevalence of Class 1 and 2 Integrons in Multi-drug Resistant Escherichia coli Isolated from Aquaculture Water in Chaharmahal Va Bakhtiari province, Iran. Annals of Clinical Microbiology and Antimicrobials, 14. https://doi.org/10. 1186/s12941-015-0096-y

Tani S, Kawauchi K, Atsumi W, Matsuo R, Ashida T, Imatake K, Suzuki Y, Yagi T, Takahashi A, Matsumoto N, Okumura Y. 2021. Association Among Daily Fish Intake, White Blood Cell Count, and Healthy Lifestyle Behaviors in an Apparently Healthy Japanese Population: Implication for the Antiatherosclerotic Effect of Fish Consumption. Heart and Vessels. https://doi.org/10.1007/s00380-020-01769-9

Tendencia EA, de la Peña LD. 2001. Antibiotic Resistance of Bacteria from Shrimp Ponds. Aquaculture, 195(3): 193-204. https://doi.org/10.1016/S0044-8486(00)00570-6

Tidwell JH, Allan GL. 2001. Fish as Food: Aquaculture's Contribution. Ecological and Economic Impacts and contributions of Fish Farming and Capture Fisheries. EMBO Reports, 2(11): 958-963. https://doi.org/10.1093/emboreports/kve236

Tolon T. 2017. Sustaining Consumer Confidence in Middle East Aquacultuer Secured by Traceability Systems. Journal of Aquaculture Engineering and Fisheries Research, 3: 44-50. https://doi.org/10.3153/JAEFR17006

Towers L. 2012. UN Welcomes \$66 Million for Ag, Fishing Projects in Saudi Arabia. The Fish Site. https://thefishsite.com/articles/un-welcomes-66-million-forag-fishing-projects-in-saudi-arabia [Accessed on 14.07.21]

Towers L. 2013. World's Most Technologically Advanced AquaFarm Launched in Abu Dhabi. The Fish Site. https://thefishsite.com/articles/worlds-most-technologicallyadvanced-aquafarm-launched-in-abu-dhabi

Towers L. 2014. FAO report: Fisheries and Aquaculture Markets in the Middle East. The Fish Site. https://thefishsite.com/ articles/fao-report-fisheries-and-aquaculture-markets-in-themiddle-east

Trivedi K, Le V, Nelson JR. 2021. The Case for Adding Eicosapentaenoic Acid (Icosapent Ethyl) to The ABCs of Cardiovascular Disease Prevention. Postgraduate Medicine, 133(1): 28-41. https://doi.org/10.1080/00325481.2020. 1783937

Waite R, Phillips M, Brummett R. 2014. Sustainable Fish Farming: 5 Strategies to Get Aquaculture Growth Right. World Resources Institute. https://www.wri.org/blog/ 2014/06/sustainable-fish-farming-5-strategies-getaquaculture-growth-right [Accessed 18 March 2021]

WHO, FAO, 2011. Report of The Joint FAO/WHO Expert Consultation on The Risks and Benefits of Fish Consumption, 25-29 January 2010, Rome, Italy (No. 978; p. 50). World Health Organization.

Zmysłowska I, Korzekwa K, Szarek J. 2009. Aeromonas hydrophila in Fish Aquaculture. Journal of Comparative Pathology, 141: 313. https://doi.org/10.1016/j.jcpa.2009.08. 143 